\title{
The Factors Affecting Overall Performance in Japanese Firms: An Analysis among Environment, Strategy, Structure and Performance
}

IN WOO JUN ${ }^{*}$

This study examined factors affecting overall performance in Japanese trading conglomerates by analyzing the relationships among business environment, competitive strategy, organizational structure, and performance.

As in the previous literature, this research also found that a firm's performance is not determined by a single factor, but can be achieved through a combination of all elements such as strategy and organizational structure. However, contrary to our general understanding, one notable finding is that the environmental variables are not deemed as main obstacles for Japanese trading firms that hinder their overall performance. Although in the past, environmental uncertainty and complexity were regarded as a barrier that had to be overcome, they seem to be considered an essential prerequisite for Japanese trading conglomerates to attain their goals at present.

This study also investigated the competitive strategy which Japanese trading firms are pursuing at this moment. Against Porter's original approach, they can in some cases adopt more than one strategy at a time from the generic strategies. This implies that Japanese trading firms may not create and sustain competitive advantage with a single specific strategy in today's highly competitive business environment. For this reason, they mix two or more competitive strategies at once in order to respond against a highly competitive business environment.

Keywords: Competitive Strategy, Decentralization, Uncertainty, Formalization, Complexity, Japanese General Trading Company

\footnotetext{
Direct all correspondence to in Woo Jun, Ph.D., Department of International Trade, University of Incheon, 12-1 Songdo-dong. Yeonsu-gu, Incheon, 406-840, Korea; Tel: 82-32-835-8935:

E-mail: captainkirk@hanmail.net
} 


\title{
I. INTRODUCTION
}

\begin{abstract}
A fter World War II, no other country enjoyed more economic success than A Japan. The Japanese economic pie grew at an annual rate of $10 \%$ from the mid-1950s until the Arab oil shocks of the early 1970s. The Japanese government thereafter managed to maintain more modest but steady growth until the early 1990s (Ellington, 2004, 1). However, after the collapse of the bubble economy, the Japanese economy had been exposed to the mega-trend of dramatic change in many aspects including finance and management sweeping Japan and the world, and the trading industry was no exception (Japan Foreign Trade Council, 2010).
\end{abstract}

Looking back on Japan's trading industry, Japan started to pay attention to the international market with the start of the Meiji era in 1868. Since then the trading business has become one of the most important industries in Japan in promoting national economic development.

In Japan today, there are more than 11,000 trading companies, but only a few hundred are engaged in trade with foreign countries (UNCTAD, 2005). Among them only seven firms, such as Mitsui Co. \& Letd., Mitsubishi Corporation, Sumitomo Corporation, Marubeni Corporation, and Itochu Corporation are classified as General Trading Companies (GTCs).

As one of the core firms within the Keiretsu Group, which is the Japanese equivalent of Korean Chaebuls, Japanese General Trading Companies (JGTCs) have been playing crucial roles for the development of Keiretsu groups with a wide range of activities. These include trading and transactional intermediation, business incubation and management, market development, financial services, information gathering, logistics, large-scale project organization, risk management, and so on.

JGTCs have also contributed to the development of national economic growth since their foundation. They have carried out an unusually important role in facilitating international trade between Japan and the rest of the world. They exist at the center of Japan's global economic effort and serve as intermediaries for half of their country's exports and two-thirds of their imports; JGTCs handle more than half of Japan's total foreign trade and much of their domestic transactions (2009, 190).

However, external and internal business environments have not favorably influenced JGTCs' business since the early 1990s. The rapidly changing business environment has threatened the future business of JGTCs and their future does nor look bright. For instance, their stable growth trend headed toward a drastic decline deadlock in 1990 due to the collapse of Japan's bubble economy in the early 1990 s (i.e., internal environment). Further, the changing international business circumstances such as the liberalization of trade and investment, inauguration of the World Trade Organization (WTO), spread of regional and bilateral 
free trade agreements (FTA), penetration of global standards, economic advancement in developing countries, and China's rise and admission to the WTO have become significant barriers that interrupts JGTCs' further growth (i.e., external environment). As the environment for JGTCs does not tend to be stable, but is perpetually changeable, they are in need of strategic management to lead a revolution which will best position them to capitalize on the opportunities and threats of the global markets.

Based on the above sets of arguments, this paper attempts to examine JGTCs' strategic management by analyzing the structural relationship between the business environment, competitive strategy, organizational structure, and performance. Although there have been some studies relating to JGTCs until recently, there have been no appropriate research approach with regard to JGTCs' strategic management point of view. Rather, most of them have merely narrated general information by covering narrow areas, such as JGTCs' functions, financial performance, or global networks. It, therefore, is worth investigating a number of elements surrounding JGTCs with a further extended managerial perspective.

\section{JGTCS AND JAPANESE ECONOMY}

$\mathrm{Up}_{\mathrm{p}}$ in until the Meiji Restoration, Japan had been in almost complete isolation from the rest of the world because there had been no capable traders who were familiar with international trade. The Meiji government, therefore, encouraged the Zaibatsu, large Japanese conglomerates controlled by powerful families, to participate in the trading industry in order to protect the domestic economy from Western invasion and promote national economic growth.

FIGURE 1. CHANGES OF JGTCs' SALES VOLUME

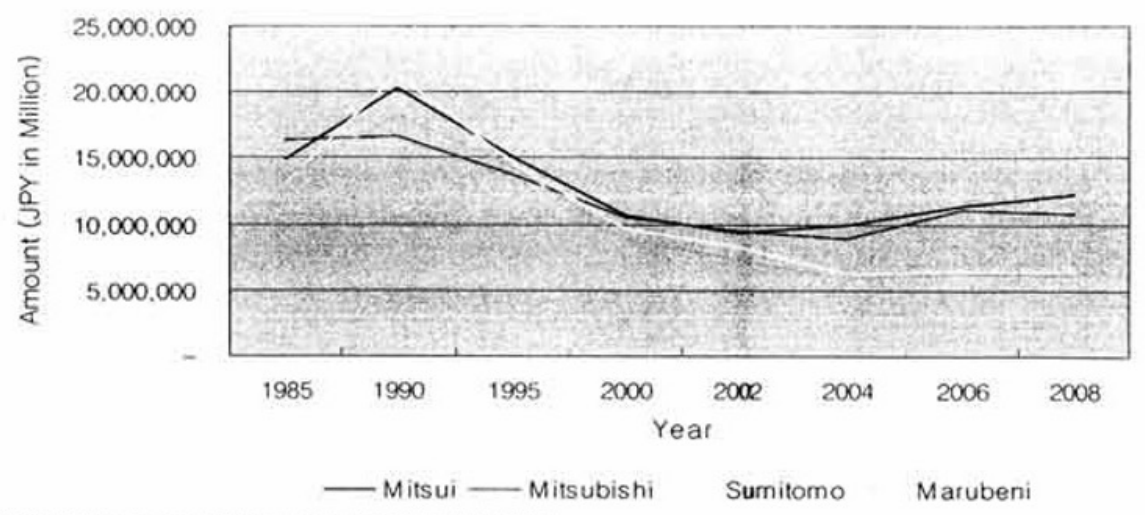

SOURCE: Japan Foreign Trade Council (2008). 
With the active assistance of the government, the Mitsui Group established its trading company in 1876, and since then, Japan's trading industry has continued to prosper for over a century. Since their foundation, most JGTCs have clung on quantitative growth by focusing on visible turnover. For example, from 1985 to 1990 , seven JGTCs achieved a steady growth of sales volumes that were an average of $13.7 \%$. However, their constant growth rate started to decline in 1991 due to the collapse of Japan's bubble economy (See Figure 1). In 1990, Mitsui Corporation's sales volume, for example, was JPY20,300,100 million. However, it has been gradually declining since 1991 and amounted only to JPY12,291,218 million in 2008 (Japan Foreign Trade Council 2010),

Despite JGTCs' continuous contribution to the development of the national economy, their future will not likely be the same as in the past due to several factors, as pointed out by Shao and Herbig (1993, 49-51). First, Non-keiretsu companies, such as Honda, Sony, and Toyota are setting up their own direct exporting network rather than exporting through JGTCs. Thus, JGTCs handle less of Japan's exports. Second, the growth potential inside Japan is limited, due to the large share of JGTCs. Third, the rise of other countries' GTCs will threaten the JGTCs in the global market. For instance, Korean GTCs have become substantial in scope and size. Last, JGTCs will face greater competition in international trade from manufacturers, smaller specialized trading companies, and foreign companies.

At the same time, the birth of the WTO in 1995 have forced JGTCs to confront new business environments. The WTO deals predominantly with the actions of governments, establishing discipline over trade policy instruments such as tariffs, quotas, subsidies, or state trading (Hoekman and Kostecki 2001, 37). The launching of the WTO means that the world trade system enters into infinite competition by reducing tariffs for imported materials or eliminating tariff barriers and ultimately establishing a tariff-free trade market.

\section{THEORETICAL BACKGROUND AND HYPOTHESES}

As reviewed in the previous chapter, the business environments surrounding JGTCs are in the midst of momentous and rapid change. To surmount these obstacles and to be real global merchants who can contribute to the world's economic advancement, JGTCs may need to pursue self-reform through strategic management by the constant scanning of the business environment, adopting competitive strategy, restructuring organizational structure, and examining the correlation between the above factors and a firm's performance.

Analyzing the relationships between the business environment, competitive strategy, organizational structure, and performance has traditionally been considered one of the main tasks in the area of strategic management, and a number 
of studies have been established to explore the structural relationship of these four elements (Chang and Choi, 1988; Chathoth and Olsen, 2007; Govindarajan, 1988; Gyampah and Acquaah, 2008; Kang, 2002; Krickx, 2000; Kwon et al., 1999; Miller, 1988). Most of the previous studies have found that a firm's performance is not determined by a single factor, but affected by all elements such as environment, strategy, and structure. In other words, a firm's performance is not dependent on one element only, but can be achieved through combination of all elements.

On the other hand, a number of studies relating to JGTCs have been carried out by many researchers since 1980s.' However, there have been no relevant studies from a strategic management approach, while most previous literature has been carried out to investigate other aspects of JGTCs such as their nature, history, functions, characteristics, financial performance, global networks, etc.

As the business environment of the world's commerce and trading industry are constantly changing, there is a need for continuous studies in approaching this from a new managerial perspective. For this reason, further expanding from the existing literature, it is worth examining the relationship between environment, strategy, structure, and performance within JGTCs.

\section{The Relationship between Environment and Performance}

As the modern business environment for firms becomes uncertain and complex, the environment for most organizations will become less predictable in the future. Such uncertainty and complexity threaten all managers attempting to think strategically and the success of an organization's future will heavily depend on the right and immediate responses to external environmental changes. Wheelen and Hunger (2007) explain today's business environment as follows:

"Most industries today are facing an ever-increasing level of environmental uncertainty. They are becoming more complex and more dynamic. Industries that used to be multi-domestic are becoming global. New flexible, aggressive, innovative competitors are moving into established markets to erode rapidly the advantages of large previously dominant firms (pp. 89-90)."

Krickx $(2000,310)$ argued that uncertainty is a key concept for organization theory and strategic management. Kabadayi, Eyuboglu and Thomas $(2007,197)$ stressed that complexity refers to the number and diversity of competitors, suppliers, buyers and other environmental actors which firm decision-makers must consider in formulating their strategies.

It, therefore, is vitally important to analyze the environmental variables surrounding the firm because environmental analysis helps to develop sustainable competitive advantage, identify opportunities and threats, promote performance, and may provide opportunities for productive co-operation with other organizations when the firm establishes a specific corporate strategy. 
From JGTCs' point of view, they have been surrounded by macro and micro environmental uncertainty and complexity. For instance, the collapse of the bubble economy starting in the early 1990s and globalization and liberalization of the national economy would be major macro environmental variables that greatly influenced their performance. Micro environmental variables, such as high competition between existing firms, and small- and medium-sized enterprises' preference for their own independent business also affected the management and pertormance of the JGTCs. In support of the above set of arguments, the following hypothesis with regard to the environment and performance is formulated as follows:

Hypothesis 1: The environmental variables (i.e. uncertainty and complexity) surrounding JGTCs will inversely affect their overall performance.

\section{The Relationship between Strategy and Performance}

The ultimate goal of an organization is to create and rctain competitive advantage over its competitors. Competitive strategy, often called business-level strategy, is the basis on which a business unit may achieve competitive advantage in its market and is concerned with developing market opportunities, new products, and services.

There are many sources of competitive strategies by which firms may create and sustain competitive advantage. As sources of a firm's competitive advantage, Porter $(1985,11-16)$ identified three generic ways in which a firm can gain a sustainable competitive advantage over other firms in its industry: differentiation, low cost, and focus.

Of the many ways suggested of creating a firm's competitive advantage, this paper chooses to use Porter's generic strategies of 'differentiation' and 'low cost,' and Johnson and Scholes' $(2002,320)$ 'hybrid' strategies. 2 However, Porter's original approach to competitive strategies was that firms can only be successful if they adopt either a differentiation or low cost strategy. But, previous researchers have established that Porter's generic strategies are not mutually exclusive-a firm can pursue several simultaneously (Dess and Davis, 1984; Hambrick, 1983; Kang, 2002; Kwon et al., 1999; Miller, 1988). In support of previous studies, this paper also adopts this position.

A firm pursuing a differentiation strategy, in particular a differentiated prospector strategy, may concentrate its efforts on gaining market share and new customers by exploiting new markets and developing new products or services in order to preoccupy markets at its competitors' expense. This argument was also presented by Miles and Snow (1978, 65-67). They stressed that the differentiated prospector's prime capability is to find and exploit new markets and products, enact dynamically by continually modifying its product-market domain to take advantage of perceived opportunities, and emphasize flexibility in its technology and administrative system 
in order to facilitate rapid adjustment. Olson, Slater and Hult (2005, 58-60) also supported this argument with the contention that differentiated prospectors are the most marketing-oriented of all types of strategists and the key to their success is the development of new products and entry into new markets.

The main purpose of the low cost strategy is to increase profitability and business effectiveness rather than gaining a bigger market share, based on stable existing markets, accumulated technologies, and sophisticated labor power through internal formal budget controls. Miller $(1988,287)$ argued that a firm tends to undertake low cost strategy under stable and predictable environments with a strong emphasis on profitability by controlling the budget. A similar argument was also presented by Miles and Snow (1978, 47-48). According to them, low cost defenders typically grow by penetrating deeper into their current markets. This type of growth is facilitated by a narrow and stable domain which allows the organization to become thoroughly familiar with client or customer needs. Consequently, firms pursuing a low cost defender strategy concentrate on profitability rather than gaining market share, by emphasizing existing and stable markets.

Further to Porter's generic strategies, Johnson and Scholes (2002, 320) suggested eight different ways on the strategy clock, of which 'hybrid' involves how managers might think about competitive strategy. The success of the hybrid strategy depends on the ability both to understand and to deliver enhanced value in terms of customer needs, while also having a cost base which permits low prices and is sufficient for re-investment to maintain and develop the bases of differentiation (Johnson and Scholes, 2002, 326). A good example is the strategy of Japanese saloon car manufacturers in the late 1980s in the European market. They provided cars to customers with better quality at competitive and reliable prices which were better than their rivals. The hybrid strategy could be advantageous as an entry strategy into a new market. This strategy could be the strategic approach to new market development which Japanese firms have used in the past.

From JGTC' perspectives, some JGTCs may select an aggressive differentiation strategy to dominate the market or acquire competitive advantage to advance ahead of competitors. For this reason, some of them adopt the strategy of scale economics by selling large quantities of commodities for a low margin of profit, and this strategy may ultimately contribute to the overall performance. Another choice that JGTCs could adopt is a combined strategy, called a 'hybrid.' As previous studies suggested, Porter's original approach for generic strategies are not mutually exclusive, but a firm can pursue several simultaneously. Therefore, some JGTCs may adopt a combined strategy to cope with the existing rivals and reinforce their competitiveness. Based on the above sets of arguments, the following hypothesis relating to strategy and performance are derived:

Hypothesis 2: JGTCs' adoption of competitive strategies (i.e. differentiation, low cost. or bybrid) will positively affect their overall performance. 


\section{The Relationship between Structure and Performance}

As an organization becomes more diverse with its products or strategies, there is a great likelihood that it will need to consider its structure. Specifically, more complex forms of organizational structure may be necessary because the center becomes increasingly isolated from the place where decisions are needed and can best be made. Thus, it is necessary to ailow the free flow of ideas from all members (i.e. decentralization) rather than centralizing the decision-making process.

Previous research investigated between organizational decentralization and a firm's performance. Govindarajan $(1988,833)$ found that high decentralization is an appropriate response to increased uncertainty. According to Govindarajan, as a task environment becomes more uncertain, there will be need for more information. Centralization is possible at low levels of uncertainty because the information processed does not overburden the organization's hierarchy. However, as uncertainty increases, more exceptions arise, which must be referred upward in the hicrarchy. As more exceptions are referred upward, the hierarchy becomes overloaded. As a result, serious delays develop between the upward transmission of information about the new situation, and a downward response to that information. An effective way to deal with such a situation is to move the level of decision-making to where information exists rather than to bring it upward in the hierarchy. A similar argument is suggested by Stoner, Freeman and Gilbert $(1995,360)$ that decentralization is the best way to develop and retain a close relationship with customers because functional-level employees possess a better understanding of customers' needs and local economic trends. As a result, this may encourage employees' commitment and involvement, and utilize their initiative if the organization gives them considerable power to make functional-level decisions.

Formalization is defined as the degree to which formal rules and procedures govern decisions and working relationships. Dalton et al. (1980, 58) argued that two distinct points of view are evident with respect to formalization and performance. Without a minimum level of formalization and standardization, role ambiguity may occur, and it affects members' attitude and performance. On the contrary, formalization and standardization may limit job scope, resulting in boredom, alienation, job dissatisfaction, absenteeism, high turnover and low output. Tata and Prasad $(2004,252)$ found similar results that organizational formalization moderates the influence of self-management on the judgments of team effectiveness. Formalized mechanisms of control restrict team members' ability to perform a variety of tasks as well as the degree to which they can exercise authority while carrying out these tasks. Consequently, this may cause lower performance. Putting all the arguments together, it can be concluded that, in order to achieve higher performance, a firm needs an optimal level 
of formalization, but not excessive formalization which may limit job scope and cause job ambiguity.

It is worth applying the above sets of arguments to JGTCs. All JGTCs have highly multi-divisional structures. ${ }^{3}$ In this highly diversified organizational structure, it would be hard for each Strategic Business Unit (SBU) to fulfill its specific strategy if decision-making authority is centralized to the higher echelons of managerial hierarchies, or jobs and decision power are controlled by formal rules. By contrast, it may encourage each SBU's motivation to implement its strategy effectively if the decision-making authority is delegated to the functional level. As a result, the above sets of arguments lead to the following two hypotheses:

Hypothesis 3a: JGTC' adoption of organizational decentralization will positively affect their overall performance.

Hypothesis 3b: JGTC' adoption of organizational formalization will inversely affect their overall performance.

\section{METHODOLOGY}

\section{Population and Sample}

The sample of this research is restricted to employees in marketing and sales SBUs within seven JGTCs-Mitsui Co. \& Led., Mitsubishi Corporation, Sumitomo Corporation, Marubeni Corporation, Itochu Corporation, Toyota Tsusho Corporation, and Sojitz Corporation. The reasons for restricting the sampling were two: (1) this research is to examine only business-level strategy (competitive strategy), and (2) being limited to a single function of SBU might increase data consistency.

In the above seven firms, there were in total 29,655 employees. Of the 29,655, there were 13,938 (approximately $47 \%$ of all employees) marketing and sales staff. Regarding the sample selection from the population, a Simple Random Sampling (SRS) is used, which is one of the of probability sampling methods. The calculation formula of the sample size in SRS is adapted from the book "Sampling: Design and Analysis" by Lohr (1999, 40).

$$
n=\frac{z_{u / 2}^{2} \cdot s^{2}}{e^{2}+\frac{z_{u / 2}^{2} \cdot s^{2}}{N}}
$$

where;

$n$ : Sample size,

$s^{2}$ : Sample variance,

e: Maximum tolerance error, 
$\mathrm{N}$ : Population number,

$z_{a / 2}$ : the value that has $\mathrm{a} / 2$ area to the right in standard normal distribution and

a: Significancè level.

Based on the above formula, the sample size $(n)$ can be calculated as follows:

$$
n=\frac{(1.96)^{2} \cdot(1)^{2}}{(0.15)^{2}+\frac{(1.96)^{2} \cdot(1)^{2}}{13,938}}=168
$$

According to the table of standard normal distribution, $z_{u / 2}$ is 1.96 when the significance level $(a)$ is $0.05(5 \%)$, which is the most commonly used level in the social sciences.

\section{Data Collection}

The principal means of data collection for this study is a mailed questionnaire survey. A cover letter was sent explaining the purpose of the study and assuring the confidentiality of the responses. Respondents received return envelopes in which to send the completed questionnaires directly back to the author, in order to minimize response bias.

When questionnaires were collected, the job position allowed a division into four groups: general staff $(24.7 \%)$, assistant manager $(33.8 \%)$, manager $(23.4 \%)$, senior manager $(16.9 \%)$ and others $(1.3 \%)$. The period of working experience allowed another division into four groups: those with less than 5 years' $(26.0 \%)$, 5 to 10 years' $(24.7 \%), 10$ to 15 years' $(24.7 \%)$ and over 15 years' $(24.7 \%)$ experience. ${ }^{4}$

168 questionnaires in total were distributed on the basis of the sample selection calculated from the population. Of the 168 marketing and sales SBU members who received questionnaires, $77(45.83 \%)$ responded. 5

\section{ANALYSIS AND RESULTS}

\section{Descriptive Statistics and Validity Analysis}

The below table shows the value of Mean and Standard Deviation of each item included in the questionnaire, and presents the result of Factor Analysis. The questionnaire is divided into four sections. A five-point Likert scale raging from 'agree strongly' to 'disagree strongly' was used to measure each section of the variables. Section one is designed to measure the business environment 
of the JGTC industry. To measure them, 12 items were cited or modified on the basis of previous studies (Kang 2002; Olson, Slater and Hult 2005) and some of them were developed by the author. Section two is designed to measure the strategy variables. This study used Porter's $(1980 ; 1985)$ generic strategies and Bowman's (1995) hybrid strategy. To measure them, a total of 24 items were designed on the basis of Kang's (2002) and Miller's (1998) scales. Section three is developed to measure variables concerning organizational structure. 17 items were adapted and developed, on the basis of studies by Govindarajan (1988) and Olson, Slater and Hult (2005) to measure decentralization and formalization. Section four is designed to measure overall performance, and 10 items were developed to cover the variables with respect to performance. Finally, a separate section is given to respondents in order to classify the present strategy that JGTCs are adopting at present.

Before testing the hypotheses, the validity analysis was undertaken in order to check how a test procedure accurately measures what it was designed to measure. This study used a Factor Analysis to test a Construct Validity, and adopted a Principal Component Analysis with Varimax Rotation.

\section{Table 1. Mean, Standard Deviation and Factor analysis Resulit}

Section 1. Environment

\begin{tabular}{|c|c|c|c|c|c|}
\hline \multirow{2}{*}{ Item } & \multirow{2}{*}{$\mathrm{N}$} & \multirow{2}{*}{ Mean } & \multirow{2}{*}{ s1) } & \multicolumn{2}{|c|}{ Factur } \\
\hline & & & & Uncert.unt) & Complexity \\
\hline 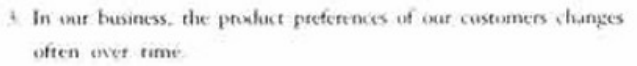 & 77 & 2.92 & 9: & .753 & $10 \mathrm{~s}$ \\
\hline 6. The life cyde of our prodects and servees at present is sluere. & 77 & 3.03 & $9+6$ & .740 & .039 \\
\hline $\begin{array}{l}\text { The new preducts and serveces of out comperitors are currently } \\
\text { frequently released in the market }\end{array}$ & 77 & 3.61 & 910 & .736 & -615 \\
\hline 2. It is difficult to forctist the netels and testes of out custumers & 7 & ios & sss & .557 & 337 \\
\hline $\begin{array}{l}\text { 4. Our custumers tend to lonk for new products and services to } \\
\text { satisfy their needs. }\end{array}$ & 77 & 2.58 & 951 & .542 & .146 \\
\hline 5. Actions of competitors are difficule to predict. & 77 & 2.82 & .807 & .513 & .172 \\
\hline 12 Potential entrants threaren the market. & 77 & 2.61 & .861 & .435 & 197 \\
\hline 16. The market is hughty comperitive & 77 & 2.12 & 811 & .035 & .805 \\
\hline 9. It is complex fir us to develoy new products and serveces & 77 & 2.47 & 912 & -047 & .706 \\
\hline 11. There are many compering produces and services. & 77 & 2.25 & 797 & .146 & .674 \\
\hline 1. It is difficult to predict market erends. & 7 & 2.55 & 911 & 463 & .585 \\
\hline 8. In our business, the channel of distribution is complex. & 77 & 3.01 & 925 & 088 & 316 \\
\hline
\end{tabular}


Section 2. Strategy

\begin{tabular}{|c|c|c|c|c|c|c|}
\hline \multirow[b]{2}{*}{ Item } & \multirow[b]{2}{*}{$\mathrm{N}$} & \multirow[b]{2}{*}{ Mean } & \multirow[b]{2}{*}{ SD } & \multicolumn{3}{|c|}{ Factur } \\
\hline & & & & Hybrid & $\begin{array}{l}\text { Ditferen- } \\
\text { tiation }\end{array}$ & $\begin{array}{c}\text { Cost } \\
\text { I.c.utership }\end{array}$ \\
\hline $\begin{array}{l}\text { 23. We are able to offer high-quality products and } \\
\text { services to our customers based on vur compertive } \\
\text { distribution channel, logistics, and transport } \\
\text { systems that redece costs. }\end{array}$ & 77 & 2.52 & 883 & .772 & -.076 & -.046 \\
\hline $\begin{array}{l}\text { 21. We maintain long-term relarionships with our } \\
\text { regular suppliers who offer us high-quality } \\
\text { products and services at lower prices. }\end{array}$ & 77 & 2.26 & 965 & .736 & -.077 & .328 \\
\hline $\begin{array}{l}\text { 22. Our regular buyers purchase our products and } \\
\text { services on the basis of high quality and fower } \\
\text { prices. }\end{array}$ & 77 & 2.41 & 819 & .713 & .033 & .112 \\
\hline $\begin{array}{l}\text { 20. We always try to find suppliers who offer us } \\
\text { high-quatity products and services at lower prices. }\end{array}$ & 77 & 2.34 & 926 & .679 & .087 & .215 \\
\hline $\begin{array}{l}\text { 10. We frequently analyze the strategies of our } \\
\text { competitors. }\end{array}$ & 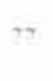 & 2.61 & 801 & .631 & .098 & 207 \\
\hline $\begin{array}{l}\text { 6. We rapidly respond to customers' hanging mexds } \\
\text { and rastes. }\end{array}$ & 77 & 2.12 & $8(1) 1$ & .550 & 304 & 154 \\
\hline $\begin{array}{l}\text { 18. We wse a high-quality and low price strategy } \\
\text { when entering into new markets: }\end{array}$ & $\cdots$ & 2.61 & 817 & .91 & 401 & -118 \\
\hline $\begin{array}{l}\text { 1. W'e use product/service innowations as a means } \\
\text { of competing. }\end{array}$ & $m$ & $2-1$ & $8(y)$ & +78 & 023 & 371 \\
\hline 9. We try to enhance our corporate image. & $\rightarrow$ & 2.13 & sis & .436 & 252 & .155 \\
\hline $\begin{array}{l}\text { 4. We always try to be ahcid of comperitors in } \\
\text { product nenelty or spect of innoration. }\end{array}$ & $\rightarrow$ & 268 & .768 & .404 & 228 & 310 \\
\hline $\begin{array}{l}\text { 19. We offer a wide range of good quality products } \\
\text { and services at lower prices than our rivals }\end{array}$ & 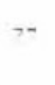 & 260 & 831 & .397 & 233 & -390 \\
\hline $\begin{array}{l}\text { 3. Our annual percentaje of sales spent on costs } \\
\text { of initiating and implementing product-market } \\
\text { innovation is high. }\end{array}$ & 77 & 2.99 & $80 ;$ & .255 & .745 & 086 \\
\hline $\begin{array}{l}\text { 2. Our annual R\&D costs for development of } \\
\text { products and services are high. }\end{array}$ & 77 & 3.11 & .969 & -.094 & .669 & .027 \\
\hline $\begin{array}{l}\text { 8. We invest heavily in advertising, sales promotion, } \\
\text { and public relations. }\end{array}$ & 77 & 291 & 906 & -.199 & .659 & -.162 \\
\hline $\begin{array}{l}\text { 24. To deliver high-quality products and service } \\
\text { to our customers at low-cost, we reinvest in R\&D. }\end{array}$ & 77 & 2.90 & 940 & .031 & .646 & .074 \\
\hline $\begin{array}{l}\text { 7. We continuously develop new products and } \\
\text { services to meet customers' needs. }\end{array}$ & 77 & 2.64 & .857 & .358 & .513 & 012 \\
\hline $\begin{array}{l}\text { 5. We pursuc a tough "undo the competitors" } \\
\text { philosophy. }\end{array}$ & 77 & 2.73 & .700 & 206 & .479 & 194 \\
\hline 12. We try to minimize advertising expenditures. & 77 & 2.95 & 857 & 028 & .144 & .738 \\
\hline $\begin{array}{l}\text { 17. All employees fully understand the need for } \\
\text { cose reduction. }\end{array}$ & 77 & 2.31 & .765 & .380 & -158 & .642 \\
\hline 16. We try to cut administrative expenses. & 77 & 2.31 & .748 & .021 & -106 & .594 \\
\hline 11. We use cost centers and fix standard costs & 77 & 2.78 & .772 & -153 & .227 & .583 \\
\hline
\end{tabular}


analyzing variances for cust control.

13. We have a strong proclivity for low-risk projects with normal and certain rates of return.

$\begin{array}{lllll}77 & 2.69 & 877 & .193 & -.011\end{array}$

14. We try to control levels of inventory.

$\begin{array}{lllll}77 & 2.22 & .700 & .456 & -238\end{array}$

15. All employees are appointed to their posts with consideration to their productivity.

$\begin{array}{lllll}77 & 2.45 & .660 & .194 \quad 196\end{array}$

\section{Section 3. Organizational Structure}

\begin{tabular}{|c|c|c|c|c|c|}
\hline \multirow{2}{*}{ Item } & \multirow{2}{*}{$\mathrm{N}$} & \multirow{2}{*}{ Mean } & \multirow{2}{*}{$\mathrm{SD}$} & \multicolumn{2}{|c|}{ Factor } \\
\hline & & & & Decentralization & Furmalization \\
\hline $\begin{array}{l}\text { 7. Middle- and lower-level managers have substantial } \\
\text { autonomy. }\end{array}$ & 77 & 2.60 & .799 & .682 & .210 \\
\hline $\begin{array}{l}\text { 2. The individual decision maker has wide latitude in } \\
\text { the choice of means to accomplish goals. }\end{array}$ & 77 & 2.56 & 835 & .682 & .087 \\
\hline $\begin{array}{l}\text { 8. Middice and lower-level managers are allowed to } \\
\text { increase the level of expenditure for advertising and } \\
\text { promotion. }\end{array}$ & 77 & 2.84 & .796 & .657 & .099 \\
\hline $\begin{array}{l}\text { 9. Mikhlh-and lower-tevel manages are allowed to dange } \\
\text { the selling price on major prostucts of services. }\end{array}$ & 77 & 2.65 & s8s & .650 & 056 \\
\hline $\begin{array}{l}\text { 3. Middle- and lower-kevel manigers ate allowed tlexibulity } \\
\text { in getting work done. }\end{array}$ & די & 2.44 & 851 & .619 & $-1+1$ \\
\hline $\begin{array}{l}\text { 4. A person who wants to make his decision would now } \\
\text { quickly be discouraged. }\end{array}$ & 77 & 2.60 & .748 & .595 & 132 \\
\hline $\begin{array}{l}\text { 1. In your company, decisions tend not to be made at } \\
\text { a high level. }\end{array}$ & 77 & 291 & 876 & .584 & -030 \\
\hline $\begin{array}{l}\text { 5. Small matters are not referred to someone higher in } \\
\text { your company for a decision. }\end{array}$ & 77 & 2.60 & .712 & .581 & 192 \\
\hline $\begin{array}{l}\text { 10. Middle and lower-level managers are allewed to } \\
\text { increase the number of employers in a business unit. }\end{array}$ & 77 & 2.91 & 989 & .540 & 07 \\
\hline $\begin{array}{l}\text { 11. If employees wish to make their own decisions, they } \\
\text { are quickly referred to a policy manual. }\end{array}$ & 77 & 2.79 & .732 & .440 & .050 \\
\hline $\begin{array}{l}\text { 15. The communication channel in our company is very } \\
\text { much formalized. }\end{array}$ & 77 & 3.03 & .827 & -116 & .762 \\
\hline $\begin{array}{l}\text { 17. Out company persists with rlie same management } \\
\text { style rather than diversifying its management style. }\end{array}$ & 77 & 2.97 & .794 & -.237 & .737 \\
\hline $\begin{array}{l}\text { 16. Employces have only restricted access to financial } \\
\text { and management information. }\end{array}$ & 77 & 3.25 & .876 & -.073 & .569 \\
\hline $\begin{array}{l}\text { 13. Our company attaches importance to basic principles } \\
\text { and all instructions are made through formal } \\
\text { documentations. }\end{array}$ & 77 & 2.69 & .765 & .161 & .527 \\
\hline $\begin{array}{l}\text { 14. Regardless of changing conditions, our company has } \\
\text { faith in past management principles which have } \\
\text { proven effective. }\end{array}$ & 77 & 2.82 & $7 \%$ & A40 & .503 \\
\hline $\begin{array}{l}\text { 12. Individuals in your company frequently refer to it } \\
\text { as a "burcaucracy." }\end{array}$ & 77 & 2.87 & 848 & .217 & .465 \\
\hline $\begin{array}{l}\text { 6. Many important decisions are made locally rather than } \\
\text { centrally. }\end{array}$ & 77 & 2.95 & .902 & .342 & .350 \\
\hline
\end{tabular}




\begin{tabular}{|c|c|c|c|c|}
\hline \multirow[b]{2}{*}{ Item } & \multirow[b]{2}{*}{$\mathrm{N}$} & \multirow[b]{2}{*}{ Mcan } & \multirow[b]{2}{*}{$\mathrm{SD}$} & \multirow{2}{*}{$\begin{array}{c}\text { Factor } \\
\begin{array}{c}\text { Overall } \\
\text { Performance }\end{array}\end{array}$} \\
\hline & & & & \\
\hline $\begin{array}{l}\text { 1. The overall performance of our company met } \\
\text { expectations in the past year. }\end{array}$ & 77 & 2.36 & .742 & .394 \\
\hline $\begin{array}{l}\text { 2. The overall perfurmance of the business last year } \\
\text { exceeded that of our major competitors. }\end{array}$ & 77 & 2.52 & .681 & .457 \\
\hline $\begin{array}{l}\text { 3. Top management was very satisfied with the overall } \\
\text { performance of the business last year. }\end{array}$ & 77 & 2.53 & .699 & .663 \\
\hline $\begin{array}{l}\text { 4. The market share increased in the last financial year } \\
\text { compared to the previous one. }\end{array}$ & 77 & 2.51 & .700 & .596 \\
\hline $\begin{array}{l}\text { 5. The number of new customers increased in the last } \\
\text { financial year compared to the last one. }\end{array}$ & 77 & 2.47 & .736 & .726 \\
\hline 6. Employee satisfaction and retention has increased. & 77 & 2.70 & .650 & .669 \\
\hline 7. Employees speed of job handling has increased. & 77 & 2.55 & .660 & .789 \\
\hline 8. Employees are more responsive toward customers. & 77 & 2.32 & .572 & .563 \\
\hline 9. Employee empowerment has increased. & 77 & 2.71 & .723 & .710 \\
\hline 10. Employee productivity has increased. & 77 & 2.57 & .768 & .682 \\
\hline
\end{tabular}

NOTE: The figures highlighted in bold type indicates a surveyed item relevant to each factor. Each numerical figure refers to the degree of correlation with a factor, and the value ranges from - 1 to 1. Therefore, the higher an absolute value is, the more it is correlated with a factor.

TABI. 2. CORRELATION AMONG VARiables

\begin{tabular}{|c|c|c|c|c|c|c|c|c|c|}
\hline & & UN & $\mathrm{CO}$ & $\mathrm{HY}$ & DI & Cl. & DE & FO & OP \\
\hline $\begin{array}{l}\text { Uncertainty } \\
\text { (UN) }\end{array}$ & $\begin{array}{l}\text { Pearson } r \\
p \text { value }\end{array}$ & 1 & $\begin{array}{c}.000 \\
1.000\end{array}$ & $\begin{array}{l}.053 \\
.646\end{array}$ & $\begin{array}{l}.237 \\
.038\end{array}$ & $\begin{array}{l}.246 \\
.031\end{array}$ & $\begin{array}{l}169 \\
.142\end{array}$ & $\begin{array}{l}187 \\
.103\end{array}$ & $\begin{array}{l}.082 \\
.476\end{array}$ \\
\hline $\begin{array}{l}\text { Complexity } \\
\text { (CO) }\end{array}$ & $\begin{array}{l}\text { Pearson } r \\
p \text { value }\end{array}$ & $\begin{array}{l}.000 \\
1.000\end{array}$ & 1 & $\begin{array}{l}.384^{\circ} \\
.001\end{array}$ & $\begin{array}{l}.007 \\
.954\end{array}$ & $\begin{array}{l}.267^{\circ} \\
.019\end{array}$ & $\begin{array}{l}.173 \\
.133\end{array}$ & $\begin{array}{l}.060 \\
.601\end{array}$ & $\begin{array}{l}.302 \\
.008\end{array}$ \\
\hline $\begin{array}{l}\text { Hybrid } \\
(\mathrm{HY})\end{array}$ & $\begin{array}{l}\text { Pearson } r \\
p \text { value }\end{array}$ & $\begin{array}{l}.053 \\
.646\end{array}$ & $\begin{array}{c}.384 \\
.001\end{array}$ & 1 & $\begin{array}{c}.000 \\
1.000\end{array}$ & $\begin{array}{l}.000 \\
1.000\end{array}$ & $\begin{array}{l}.447^{\circ *} \\
.000\end{array}$ & $\begin{array}{r}-.232 \\
.042\end{array}$ & $\begin{array}{l}.352^{*} \\
.002\end{array}$ \\
\hline $\begin{array}{l}\text { Differentiation } \\
\text { (DI) }\end{array}$ & $\begin{array}{l}\text { Pearson } r \\
p \text { value }\end{array}$ & $\begin{array}{l}.237^{\circ} \\
.038\end{array}$ & $\begin{array}{l}.007 \\
.954\end{array}$ & $\begin{array}{c}.000 \\
1.000\end{array}$ & 1 & $\begin{array}{c}.000 \\
1.000\end{array}$ & $\begin{array}{l}.127 \\
.271\end{array}$ & $\begin{array}{l}.133 \\
.247\end{array}$ & $\begin{array}{l}.306 " \\
.007\end{array}$ \\
\hline $\begin{array}{l}\text { Cost Leadership } \\
\text { (CL) }\end{array}$ & $\begin{array}{l}\text { Pearson } r \\
\rho \text { value }\end{array}$ & $\begin{array}{l}.246^{\circ} \\
.031\end{array}$ & $\begin{array}{l}267^{\circ} \\
.019\end{array}$ & $\begin{array}{l}.000 \\
1.000\end{array}$ & $\begin{array}{c}.000 \\
1.000\end{array}$ & 1 & $\begin{array}{l}.067 \\
.562\end{array}$ & $\begin{array}{l}.315^{\circ} \\
.005\end{array}$ & $\begin{array}{l}.112 \\
.331\end{array}$ \\
\hline $\begin{array}{l}\text { Decentralization } \\
\text { (DE) }\end{array}$ & $\begin{array}{l}\text { Pearson } r \\
p \text { value }\end{array}$ & $\begin{array}{l}.169 \\
.142\end{array}$ & $\begin{array}{l}173 \\
133\end{array}$ & $\begin{array}{l}.447^{\circ} \\
.000\end{array}$ & $\begin{array}{l}.127 \\
.271\end{array}$ & $\begin{array}{l}.067 \\
.562\end{array}$ & 1 & $\begin{array}{c}.000 \\
1.000\end{array}$ & $\begin{array}{l}.229^{\circ} \\
.045\end{array}$ \\
\hline $\begin{array}{l}\text { Formalization } \\
\text { (FO) }\end{array}$ & $\begin{array}{l}\text { Pearson } r \\
p \text { value }\end{array}$ & $\begin{array}{l}.187 \\
.103\end{array}$ & $\begin{array}{l}.060 \\
.601\end{array}$ & $\begin{array}{r}-.232 \\
.042\end{array}$ & $\begin{array}{l}133 \\
.247\end{array}$ & $\begin{array}{l}.315^{\circ} \\
.005\end{array}$ & $\begin{array}{l}.000 \\
1.000\end{array}$ & 1 & $\begin{array}{l}.295 \\
.009\end{array}$ \\
\hline $\begin{array}{l}\text { Overall } \\
\text { performance (OP) }\end{array}$ & $\begin{array}{l}\text { Pearson } r \\
p \text { value }\end{array}$ & $\begin{array}{l}.082 \\
.476\end{array}$ & $\begin{array}{l}.302 \\
.008\end{array}$ & $\begin{array}{l}.352 \\
.002\end{array}$ & $\begin{array}{l}.306 " \\
.007\end{array}$ & $\begin{array}{l}.112 \\
.331\end{array}$ & $\begin{array}{l}.229^{\circ} \\
.045\end{array}$ & $\begin{array}{l}.295^{* 1} \\
.009\end{array}$ & 1 \\
\hline
\end{tabular}

NOTE: ": Significant at $\mathrm{p}<0.05 ; "$ : Significant at $\mathrm{p}<0.01$. 


\section{Correlation Matrix}

The table 2 reports the correlations for the constructs included in this study. According to the result, the value of Pearson Correlation Coefficient $(r)$, for example, between the environmental uncertainty and overall performance is 0.082 , which means that there is a correlation between two variables. For readers' reference, the table also presents the value of Pearson Correlation Coefficient for other variables.

\section{Test of Hypotheses}

To test hypotheses, we used regression analysis, and found that the regression model is statistically significant as the value of Coefficient of Determination $\left(\mathrm{R}^{2}\right)$ is $0.359(35.9 \%)$.

The author found that hypothesis 1 does not receive support. The $p$ value of environmental uncertainty and environmental complexity are 0.528 and 0.206 ( $\mathrm{p}>0.05$ ), respectively which means there is no statistical significance between variables. In other words, the result denotes that the environmental variables surrounding JGTCs do not seem to be major barriers affecting their overall performance.

Hypothesis 2 is designed to examine the relationship between JGTC's strategies and their overall performance. The $p$ value of differentiation strategy and hybrid strategy are 0.008 and $0.003(p<0.05)$, respectively which means variables are strongly significant statistically to each other. However, the result shows that there is no statistical significance between low cost strategy and overall performance $(\mathrm{p}$ value $=0.839, \mathrm{p}>0.05)$.

TABl.E 3. Results of Regression ANal.ysis

\begin{tabular}{|c|c|c|c|c|c|c|}
\hline \multicolumn{2}{|c|}{$\begin{array}{c}\text { Independent } \\
\text { Variables }\end{array}$} & $\begin{array}{c}\text { Regression } \\
\text { Coefficient }(\beta)\end{array}$ & $\begin{array}{c}\text { Standard } \\
\text { Error }\end{array}$ & t value & $\mathrm{p}$ value & VIF \\
\hline \multicolumn{2}{|c|}{ (constant) } & .000 & .096 & .000 & 1.000 & \\
\hline \multirow{2}{*}{ Environment } & Uncertainty & -.066 & .105 & -.635 & .528 & 1.178 \\
\hline & Complexity & .141 & .110 & 1.277 & .206 & 1.305 \\
\hline \multirow{3}{*}{ Strategy } & Differentiation & .273 & .101 & 2.718 & .008 & 1.090 \\
\hline & Low Cost & -.022 & 108 & -.204 & 839 & 1.263 \\
\hline & Hybrid & .377 & .121 & 3.123 & .003 & 1.573 \\
\hline \multirow{2}{*}{ Structure } & Decentralization & .015 & 110 & .132 & .896 & 1.308 \\
\hline & Formalization & 357 & .107 & 3.328 & .001 & 1.237 \\
\hline \multirow{2}{*}{\multicolumn{2}{|c|}{ Model Statistics }} & $\mathbf{R}^{2}$ & Adjusted $\mathrm{R}^{2}$ & \multirow{2}{*}{\multicolumn{2}{|c|}{$\begin{array}{c}\text { F value } \\
5.527\end{array}$}} & $p$ value \\
\hline & & .359 & .294 & & & .000 \\
\hline
\end{tabular}

NOTE: Dependent Variable-Overall PerformanceSignificant at $\mathrm{p}<0.05$. 
With respect to JGTC' organizational structure and their performance, we derived two hypotheses. According to the result, hypothesis 3 a does not receive support because the $p$ value of decentralization is $0.896(p>0.05)$. Meanwhile, in case of hypothesis $3 \mathrm{~b}$, there is a significant statistical correlation between JGTCs' formalization and their overall performance. Therefore, hypothesis $3 \mathrm{~b}$ is fully accepted ( $\mathrm{p}$ value $=0.001, \mathrm{p}<0.05$ )

\section{The Result of JGTCs' Present Strategy}

Separately, this study examined the competitive strategy which JGTCs are pursuing at this moment. Against Porter's (1985) advice, JGTCs adopt more than one strategy at once. Of 77 respondents, 38 of them answered that they can in some cases adopt more than one strategy at a time from the generic strategies.

\section{CONCLUSION AND IMPLICATIONS}

This study investigated the relationship between environment, competitive strategy, organizational structure, and performance in JGTCs by analyzing how the above three factors influence overall performance. Notwithstanding the importance of JGTCs in Japan's national economic system and in world commerce, there has been no significant study for them from a strategic management view point. In this respect, the academic contribution of this study is rooted in the fact that the existing studies of JGTCs lack a comprehensive approach that relates a managerial perspective.

According to the empirical analysis, some hypotheses are accepted, but some of them are incompatible with our prediction that needs further discussion. First, contrary to our general understanding, the environmental variables such as uncertainty and complexity are not deemed as main obstacles for JGTCs that obstruct their overall performance. However, existing literatures argue that the environmental variables are correlated with a firm's strategy, structure, or performance (Chathoth and Olsen, 2007; Govindarajan, 1988; Gyampah and Acquaah, 2008; Kang, 2002; Kwon et al., 1999; Mavondo, 1999; Miller, 1988; Olson, Slater and Hult, 2005). For instance, Mavondo (1999, 246) stresses that the environment has a significant influence on a firm's marketing effectiveness and financial performance, and a company's success is externally determined by the industry's environment. Kang's $(2002,152)$ research also reveals a similar result saying that the environmental variables such as uncertainty, dynamism and complexity significantly influence hotel firms' management performance. All things taken together, the result of this study implies that most JGTCs 
these days may consider the environmental variables as essential prerequisites in their business process rather than regard them as barriers that have to be surmounted. As the business environments surrounding JGTCs are becoming increasingly uncertain and unforeseeable, JGTCs consider that the environmental factors are no longer obstacles that hinder their business performance. In other words, it means that JGTCs need constant strategic management in order to create sustainable competitive advantages over the environmental variables.

Second, against our expectations, the result reveals that JGTCs' employment of low cost strategy is not positively associated with their overall performance. This result denotes that it is hardly possible for JGTCs to accomplish their goal if they cling to their existing customers or concentrate on narrow markets in order to save costs or control budgets under the highly competitive business environment like today. Rather, it seems that the approach to the market by JGTCs are to be more aggressive by adopting differentiation or hybrid strategies.

Third, we obtained the result saying there is no association between JGTCs' organizational decentralization and overall performance. This might be influenced by the Japanese firms' corporate culture. The typical Japanese firms' decision-making culture is consensus-style decision-making which allows all the people to take part in the entire process of defining, solving, and acting upon a problem (Matsumoto 1991, 142-154; Taplin 1995, 25-48). Ouchi (1981, 43-47) stressed that Japanese firms form inclusive relationships between the employees and the employer. In most Japanese firms including JGTCs, decisions are made on the basis of opinions and information emanating from each of the responsible parties, which are subsequently collated and used to create what is considered to be the best possible proposal for adoption. Debroux $(2003,106)$ further argued that the management system in Japan features a decentralized internal information structure which facilitates horizontal communication between functional units, whereby teams are able to resolve problems autonomously without the involvement of higher managerial levels. This result implies that organizational structure within JGTCs has already been decentralized, and, for this reason, people in JGTCs may feel there is no significant correlation between two variables.

This study has some theoretical implications. First, the structural relationship analysis between environment, strategy, structure, and performance has received much attention in the literature over time, and the sample companies of previous research include manufacturing firms, hospitality industry, financial firms, un-diversified autonomous companies, subsidiaries of diversified big enterprises, etc. Consistent with the existing studies, the existing theory works even in the highly diversified trading houses. In other words, firms' performance is not achieved independently, but determined interdependently affecting by mixed variables such as their strategies and organizational structure.

Second, an original theory of Porter's (16-18) competitive strategies works quite differently in practice. According to Porter, firms can be successful when 
they adopt only one strategy out of three generic strategies. Porter's original approach to competitive strategies is that firms can be successful only if they adopt either a cost or a differentiation strategy (i.e. they must choose one of the two). If they mix them, they end up with low perceived value and high price (i.e. stuck in the middle). However, contradicting Porter's argument, this research found that JGTCs adopt more than one strategy at a time. This implies that JGTCs may not create and sustain competitive advantage with a single specific strategy in today's highly competitive business environment. As a result, they mix two or more strategies to cope with the rapidly changing and highly competitive business environment.

\section{REFERENCES}

Bryman, A. 2004. Social Research Methods, $2^{\text {nd }}$ ed. Oxford: Oxford University Press.

Chang, S. J. and U. Choi. 1988. Strategy, Structure and Performance of Korean Business Groups: A Transactions Cost Approach. The Jounal of Industrial Economio 37(2): 141-157.

Chathoth, P. K. and M. D. Olsen. 2007. The Effect of Environment Risk, Corporate Strategy and Capital Structure on Firm Performance. Hospitality Management 26: 502-516.

Churchill, G. A. and T. J. Brown. 2004. Basic Marketing Research. Sth ed. SouthWestern: Thomson.

Dalton, D. R., W. D. Todor, M. J. Spendolini, G. J. Fielding, and L. W. Porter. 1980. Organization Structure and Performance: A Critical Review. Academy of Management 5(1): 49-64.

Debroux, P. 2003. Culture and Management in Japan. In Culture and Management in Asia, ed. M. Warner. Curzon: Routledge.

Dess, G. G. and P. S. Davis. 1984. Porter's Generic Strategies as Determinants of Strategic Group Membership and Organizational Performance. Academy of Management Joumal 27(3): 467-488.

Dicken, P. and Y. Miyamachi. 1998. From Noodles to Satellites: The Changing Geography of the Japanese Sogo Shosha. Royal Geographical Society: 55-78.

Ellington, L. 2004. Learning from the Japanese Economy. National Clearing House for US-Japan Studies. East Asian Studies Center: Indiana University.

Faulkner, D., and C. Bowman. 1995. The Essence of Competitive Strategy. New Jersey: Prentice Hall.

Govindarajan, V. 1988. A Contingency Approach to Strategy Implementation at the Business-unit Level: Integrating Administrative Mechanism with Strategy. Academy of Management Journal 31(4): 828-853.

Gyampah, K. A. and M. Acquaah. 2008. Manufacturing Strategy, Competitive 
Strategy and Firm Performance: An Empirical Study in a Developing Economy Environment. International Journal of Production Economics 111(2): 575-592.

Hambrick, D. C. 1983. High Profit Strategies in Mature Capital Goods Industries:

A Contingency Approach. The Academy of Management Journal 26(4): 687-707.

Hoekman, B. M., and M.M Kostecki. The Political Economy of the World Trading System: The WTO and Beyond. Oxford: Oxford University Press.

Japan Foreign Trade Council. 2010. "Function of Shosha." http://www.jftc.or. ip/english/home_e.htm.

Johnson, G. and K. Scholes. 2002. Exploring Corporate Strategy. $6^{\text {th }}$ ed. New Jersey: Prentice Hall.

Jun, I. W. 2009. Sogo Shosha: Its Nature and Theoretical Review of the Justification for Existence. Journal of International Trade and Industry Studies 14(4): 189-210.

Kabadayi, S., N. Eyuboglu, and G. P. Thomas. 2007. The Performance Implications of Designing Multiple Channels to Fit with Strategy and Environment. Journal of Marketing 71: 195-211.

Kang, I. S. 2002. A Study on the Structural Analysis of Management Environment. Strategy. Firm Structure and Performance in the Hotel Industry, Ph. D. dissertation: University of Kyonggi.

Kojima, K. and T. Ozawa. 1984. Japan's General Trading Companies: Merchants of Economic Development. Development Center of the Organization for Economic Co-operation and Development. OECD: 25-26.

Krickx, G. A. 2000. The Relationship between Uncertainty and Vertical Integration. The International Journal of Organizational Analysis 8(3): 309-329.

Kwon, K. H., B. S. Kim, Y. J. Kim, and S. J. Limb. 1999. Relationships between the Environment, Competitive Strategy and Organizational Structure: Performance Implication. Korean Journal of Strategic Management 2(2): 41-73. Lohr, S. L. 1999. Sampling-Design and Analysis. Pacific Grove, Calif: Duxbury Press.

Matsumoto, K. 1991. The Rise of the Japanese Corporate System, London: Kegan Paul International.

Mavondo, F. T. 1999. Environment and Strategy as Antecedents for Marketing Effectiveness and Organizational Performance. Jowrnal of Strategic Marketing 7: $237-250$.

Miles, R. E. and C. C. Snow. 1978. Organizational Strategy, Structure and Process, New York: McGraw Hill Publishing Company.

Miller, D. 1988. Relating Porter's Business Strategies to Environment and Structure: Analysis and Performance Implications. Academy of Management Journal 31(2): 280-308.

Mitsubishi Corporation. Annual Report. 2008.

Olson, E. M., S. F. Slater, and G. T. M. Hult. 2005. The Performance Implications of Fit among Business Strategy, Marketing Organization Structure and Strategic Behavior. Journal of Marketing 69(3): 49-63. 
Ouchi, W. G. 1981. Theory Z: How American Business Can Meet the Japanese Challenge, MA: Addison-Wesley Publishing Company.

Porter, M. E. 1985. Competitive Advantage. OH: The Free Press.

Shao, A. T. and P. Herbig. 1993. The Future of Sogo Shosha in a Global Economy. International Marketing Review 10(5): 37-55.

Stoner, J., R. E. Freeman, and D. R. Gilbert Jr. 1995. Management, $6^{\text {th }}$ ed. New Jersey: Prentice Hall.

Taplin, R. 1995. Decision-making and Japan. Japan Library.

Tata, J. and S. Prasad. 2004. Team Self-management, Organizational Structure and Judgments of Team Effectiveness. Joumal of Managerial Lssues 16(2): 248-265.

United Nations Conference on Trade and Development (UNCTAD). 2005. New Role for Japan's Sogo Shosha as They Shift from Manufacturing to Services. Geneva: UNCTAD Press January 20, 2005.

Wheelen, T. L. and J. D. Hunger. 2007. Strategic Management and Business Policy. 11 th ed. New Jersey: Prentice Hall.

Yamamura, K. 1985. General Trading Companies in Japan: Their Origins and Grouth: Berkeley., CA: University of California Press.

Yoshihara, K. 1982. Sogo Shosha: The Vanguard of the Japanese Economy, Oxford: Oxford University Press.

Yoshino, M. Y. and T. B. Lifson. 1986. The Invisible Link: Japan's Sogo Shosha and the Organization of Trade, MA: The MIT Press. 


\section{ENDNOTES}

For more information on JGTCs, such as their nature, functions, business activities, management system, and financial performance, see Dicken and Miyamachi (1998), Kojima and Ozawa (1984). Shao and Herbig (1993). Yamamura (1985), Yoshino and Lifson (1986) and Yoshihara (1982).

Johnson and Scholes (2002) went on to generalize the possible generic competitive strategies according to the different ways of combining Perceived Added Value and Price, based on the work of Faulkner and Bowman (1995). Instead of four discrete possibilities (i.e. differentiation, low cost, focus and stuck in the middle), they presented a continuum diagrammatically as a "clock." For more details, see Johnson and Scholes (2002, 319-322), and Faulkner and Bowman (1995, 14-17).

Mitsubishi Corporation, for example, consists of six different business groups: the new business initiative group, the energy business group, the metals business group, the machinery business group, the chemical business group and the living essentials business group. In addition, each business group has several offices, units, or divisions (Mitsubishi Corporation Annual Report, 2008).

With respect to data collecting, previous studies in this field used various Official Company Information Directories to gather the corporate-level information, or selected high-level executives to collect internal-level information. To list some of the examples, Chathoth and Olsen $(2007,510)$ used COMPUSTAT through Wharton Research Data Service, Olson, Slater and Hult (2005, 55) selected senior marketing managers as key informants, and Miller $(1988,289)$ gathered information from the chief execurive officers and most senior vice presidents. However, this study chose JGTCs' general employees as main information providers rather than used Official Company Information Directories or collected data from the top executives in JGTCs. The reasons are two. First, the purpose of this study is to focus only on JGTCs, and not on ordinary trading companies in Japan. Since only seven firms are classified as GTCs in Japan, the author was not able to use the Official Company information Directory as the use of this directory may lead to a significant lack of sample numbers. Second. the auther could not limir the research to only top executives as key informants as most were unavalable due to conflicting schedules and the nature of their work. Although top executives were not main informants, the data of this study is still representative as $74.1 \%$ of respondents had 5.15 years or more working experiences. Notwithstanding such a limitation, this study is worthy of notice because of the challenging attempt to gather primary data from general employees in JGTCs. It will be, sherefore, significant if future surveys are undertaken including top management in order to further increase the degree of representation.

Although the questionnaite response rate of $45.83 \%$ in this study is not higher. it is acceptable. According to Bryman (2004), a range of response rates were $30 \%$ to $94 \%$ in an examination of published studies in the field of organizational research in the years 1979-1983. Furthermore, Churchill and Brown (2004) argued that most Japanese businesspeople are hesitant to take part in surveys during business hours-taking time away from their work for a survey is like "stealing" from theit employer. Due to this reason, the author had some difficulties in collecting questionnaire data because most employees in JGTCs were reluctant to participate in the survey. 